\title{
Herbage allowance effects on the characteristics of Brachiaria brizantha cv. Marandu pastures and the production and economic viability of Nellore heifers
}

\section{Efeitos da oferta de forragem sobre as características das pastagens de Brachiaria brizantha cv. Marandu e na produção e viabilidade econômica de novilhas Nelore}

\author{
Alexandre Menezes Dias ${ }^{1 *}$; Eva Nara Oliveira Gomes ${ }^{2}$; Luís Carlos Vinhas Ítavo; \\ José Aparecido Moura Aranha ${ }^{3}$; Camila Celeste Brandão Ferreira Ítavo'; \\ Ériklis Nogueira ${ }^{4}$; Fabiano Ferreira da Silva ${ }^{5}$; Luciana Junges ${ }^{2}$
}

\begin{abstract}
This study aimed to evaluate the effect of three herbage allowances $(5,10$, and $15 \mathrm{~kg}$ dry matter [DM] $100^{-1}$ of body weight [BW]) for Brachiaria brizantha cv. Marandu pastures in a continuous grazing system on the morphological and nutritional characteristics of forage, animal performance, and economic viability in Nellore heifers. The total experimental area was 60 ha, divided into 12 paddocks of 5 ha each, with 4 paddocks per treatment. The experimental animals were Nellore heifers (260 in total), with average BW of $301.16 \pm 9.12 \mathrm{~kg}$, receiving $0.4 \%$ BW in multiple supplements. We evaluated the production, structural characteristics, and nutritional value of the forage, productive performance, carcass characteristics, and economic viability of each allowance. There were significant effects for the production, structural characteristics, and nutritional value of the forage treatment. The proportions of leaves were $42.40,38.20$, and $30.88 \%$ and the leaf:stem ratios were $1.22,1.03$, and 0.83 for the 5,10 , and $15 \mathrm{~kg} \mathrm{DM} 100^{-1} \mathrm{BW}$ herbage allowances, respectively. The average daily weight gain (mean 0.42 , 0.75 , and $0.63 \mathrm{~kg}$ daily $\left.^{-1}\right)$ and stocking rate $\left(3.35,1.87\right.$, and 1.26 animal unit ha $\left.{ }^{-1}\right)$ had a significant effect for the 5, 10, and $15 \mathrm{~kg}$ DM $100^{-1} \mathrm{BW}$ forage allowance, respectively. The herbage allowances were evaluated as being economically viable with a profit margin of $10.37,23.65$, and $14.43 \%$ for the 5,10 , and $15 \mathrm{~kg}$ DM $100^{-1} \mathrm{BW}$ allowances, respectively. The greatest pasture response was found in the $5 \mathrm{~kg}$ DM $100^{-1} \mathrm{BW}$ allowance and was related to better nutritional values and morphological characteristics of the pasture and greater stoking rate and weight gain per area. The herbage allowance of $10 \mathrm{~kg}$ DM $100^{-1} \mathrm{BW}$ be applied to obtain higher animal performance and better economic viability of heifers in $B$. brizantha $\mathrm{cv}$. Marandu pastures in a continuous grazing method that are receiving protein-energy supplementation.
\end{abstract}

Key words: Animal performance. Forage crops. Profitability margin. Urochloa brizantha.

\footnotetext{
${ }^{1}$ Profs., Universidade Federal de Mato Grosso do Sul, UFMS, Faculdade de Medicina Veterinária e Zootecnia, FAMEZ, Programa de Pós-Graduação em Ciência Animal, Campo Grande, MS, Brasil. E-mail: alexandre.menezes@ufms.br; luis.itavo@ufms.br; camila.itavo@ufms.br

2 Discentes, Curso de Doutorado do Programa de Pós-Graduação em Ciência Animal, UFMS, Campo Grande, MS, Brasil. E-mail: evanara06@gmail.com; ljungeszootecnia@hotmail.com

3 Prof., UFMS, Escola de Administração e Negócios, ESAN, Campo Grande, MS, Brasil. E-mail: jaranha@terra.com.br

${ }^{4}$ Pesquisador, Empresa Brasileira de Pesquisa Agropecuária, EMBRAPA Pantanal, Corumbá, MS, Brasil. E-mail: eriklis. nogueira@embrapa.br

5 Prof., Universidade Estadual do Sudoeste da Bahia, UESB, Itapetinga, BA, Brasil. E-mail: ffsilva@pq.cnpq.br

* Author for correspondence
} 


\title{
Resumo
}

\begin{abstract}
Objetivou-se avaliar o efeito de três ofertas de forragem $\left(5,10\right.$ e $15 \mathrm{~kg}$ de matéria seca [MS] $100^{-1}$ de peso corporal [PC]) em pastos de capim Brachiaria brizantha cv. Marandu em método de pastejo continuo, sobre as características morfológicas e nutricionais da forragem, desempenho animal e a viabilidade econômica de novilhas Nelore. A área experimental foi de 60 hectares (ha), divididas em 12 piquetes com 5,0 ha cada, sendo quatro piquetes por tratamento. Foram utilizadas 260 novilhas Nelore, com PC médio inicial de $301,16 \pm 9,12 \mathrm{~kg}$, recebendo $0,4 \%$ do PC de suplemento múltiplo. Foram avaliados a produção, características estruturais e valor nutricional da forragem, desempenho produtivo, características de carcaça e a viabilidade econômica das ofertas. Houve efeito significativo para a produção, características estruturais e valor nutricional da forragem. A proporção de folhas foi de 42,40 ; 38,20 e $30,88 \%$ e a relação folha:colmo foi de 1,$22 ; 1,03$ e 0,83 para as ofertas de 5,10 e $15 \mathrm{~kg}$ de MS, respectivamente. $\mathrm{O}$ ganho médio diário e taxa de lotação apresentou efeito significativo apresentando médias de 0,42; 0,75 e 0,63 $\mathrm{kg} \mathrm{dia}^{-1}$ e 3,35; 1,87 e 1,26 UA ha ${ }^{-1}$ para as ofertas de forragem 5, 10 e $15 \mathrm{~kg}$ de MS, respectivamente. As ofertas avaliadas foram economicamente viáveis apresentando margem de lucratividade de 10,37; 23,65 e 14,43\% para as ofertas com 5, 10 e $15 \mathrm{~kg}$ de MS $100^{-1}$ de peso corporal, respectivamente. A oferta de forragem de $5 \mathrm{~kg}$ de MS $100^{-1} \mathrm{PC}$ proporcionou melhor valor nutricional e características morfológicas das pastagens, levando ao aumento da taxa de lotação e maior ganho de peso por hectare. A oferta de forragem de $10 \mathrm{~kg} \mathrm{MS} 100^{-1} \mathrm{PC}$ proporcionou maior desempenho animal e melhor viabilidade econômica de novilhas em pastagens $B$. brizantha cv. Marandu em método de pastejo contínuo recebendo suplementação proteico-energética.

Palavras-chave: Desempenho animal. Forragicultura. Margem de lucratividade. Urochloa brizantha.
\end{abstract}

\section{Introduction}

In the central west region of Brazil, the continuous grazing system is still the most widely used method on farms for the production of cattle in pastures. Often, stocking adjustments are performed without defined criteria, especially for mass forage production. Given this, it is necessary to use forage production efficiently, offering enough fodder to produce satisfactory weight gains and increased productivity per area, whilst minimizing waste.

The best animal performance will be achieved when the forage production is used efficiently, taking into consideration herbage mass and stocking rate in order to control both the quality and quantity of forage (REIS et al., 2009). Grassland structure variables can provide a better understanding of animal responses and provide guidance for the management of pastures (TRINDADE et al., 2012).

Whereas it aims to achieve higher stocking rates per area in pasture production that will result in lower herbage allowance and consequently lower animal performance, while on the other hand, when seeking higher per animal weight gain it is necessary to provide a greater supply of fodder, thus enabling higher productivity and nutritional value of the forage. Some studies (BERNARDINO et al., 2011; PAULA et al., 2012; SCHIO et al., 2011) show a positive effect of herbage allowance on weight gain rates.

According to Schio et al. (2011), the best forage quality, owing to its greater availability, favors animal selectivity, i.e., heifers with more herbage allowance consume higher amounts of leaves, which are the most nutritious part of the pasture.

Dead material accumulation is the result of several factors such as a decrease in the quantity and quality of light coming through the canopy. When the height of the canopy is reduced (i.e., lower forage supply) more light reaches the base of the plant, while in the highest canopies (i.e. higher forage supply), the opposite occurs because of lower light interception owing to the lengthening of the plants and greater amount of sheets covering the soil (NANTES et al., 2013). 
There is some information in the literature (CARLOTTO et al., 2011; PAULA et al., 2012; SCHIO et al,. 2011) on herbage allowance for animal production in Brachiaria pastures; however, there is limited information regarding the best forage supply in animal production in the Cerrado ecoregion, Brazil. It is necessary to use forage supplies on pastures that do not suppress animal performance while ensuring that the system is economically efficient.

Thus, the objective of the present study was to evaluate the effect of three herbage allowance (5, 10 , and $15 \mathrm{~kg}$ total DM $100^{-1}$ of body weight [BW]) in Brachiaria brizantha cv. Marandu pastures on the morphological and nutritional characteristics of forage, the production performance, and economic viability of the production of Nellore heifers in a continuous grazing system.

\section{Materials and Methods}

The experiment was conducted at Esperança Farm in the municipality of Aquidauana-MS located at $19^{\circ} 28^{\prime} 34.5^{\prime \prime} \mathrm{S}$ and $55^{\circ} 16^{\prime} 29.5^{\prime \prime} \mathrm{W}$. Analyses were performed at the Laboratory of Biotechnology Applied Animal Nutrition at the Catholic University Don Bosco and at the Applied Nutrition Laboratory of the Federal University of Mato Grosso do Sul.

The pluviometric index of the experimental period is shown in Figure 1. The animals were distributed in a randomized design. The experimental period ran for 240 days starting in October 2013 and ending in May 2014, water period.

Figure 1. Pluviometric precipitation monthly total and collected during the experimental period from October 2013 to May 2014.

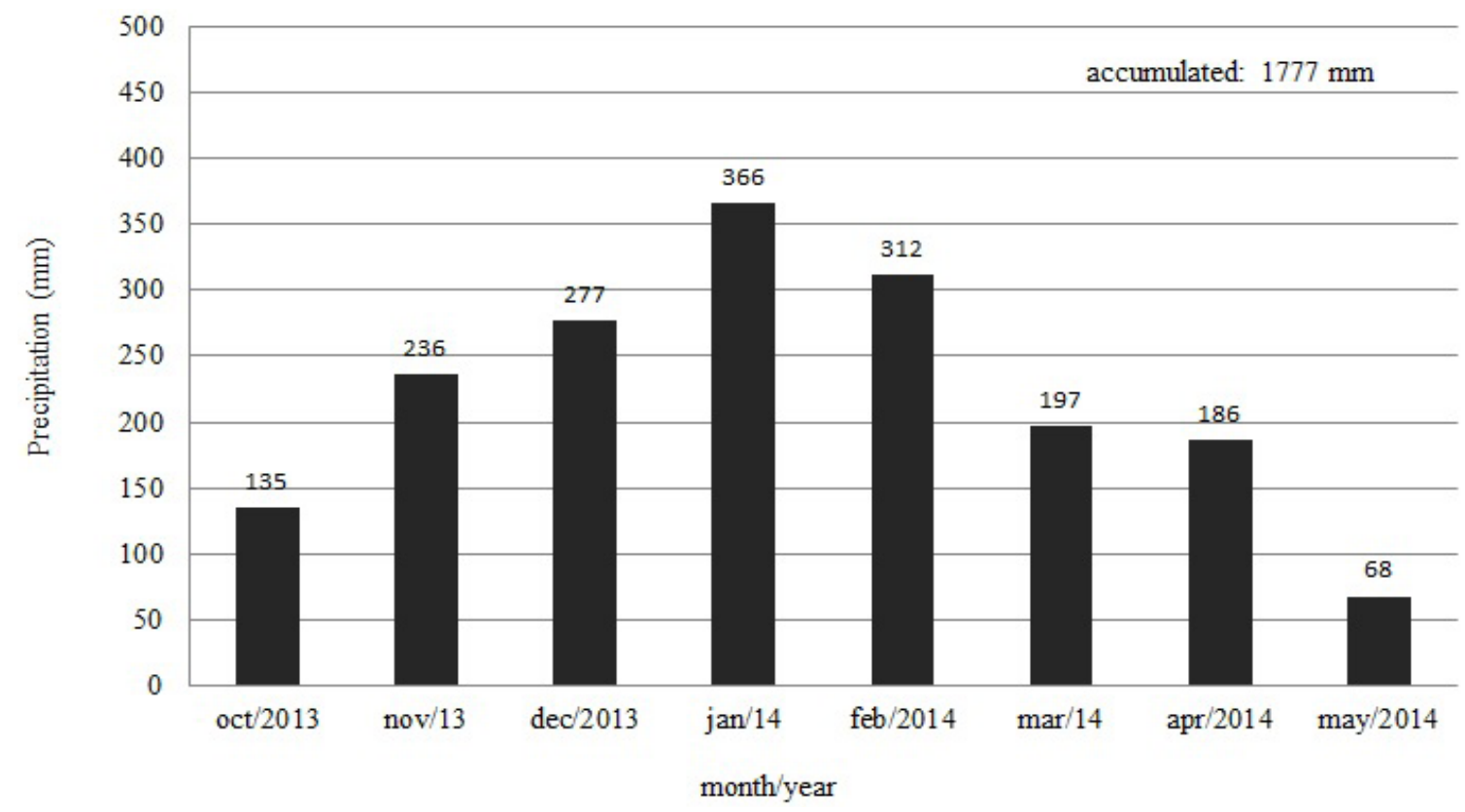

The treatments consisted of three herbage allowances of 5, 10, and $15 \mathrm{~kg}$ of dry matter (DM, leaves and stem) forage per $100 \mathrm{~kg}$ body weight (BW). Initially, 300 Nellore heifers were selected, with initial body weights averaging $301.16 \pm 9.12$ $\mathrm{kg}$. From these, 260 heifers were used in the grazing experiment to contemplate and evaluate the herbage treatments. The heifers were distributed between 12 
paddocks (experimental units), with 5 ha on average for each paddock (totaling $60 \mathrm{ha}$ ) consisting of Brachiaria (Syn. Urochloa) brizantha cv. Marandu in a continuous grazing system with variable forage treatments. For each experimental unit, five animals were considered in the evaluations from the beginning to the end of the experiment. When not in use in the experimental units, regulator animals remained in a 10 ha picket reserve, and were used in the experimental units whenever there was need for stocking rate adjustment to maintain herbage allowances.

Initially, the pasture areas showed production dry mass forage averages of $3115 \mathrm{~kg} \mathrm{ha}^{-1}$, which were made adjustments of allowance and distributed the animals in their treatments. The pasture had the following chemical composition: $302 \mathrm{~g} \mathrm{~kg}^{-1} \mathrm{DM}, 98$ $\mathrm{g} \mathrm{kg}^{-1}$ crude protein (CP) in DM and in vitro DM digestibility (IVDMD) of $560 \mathrm{~g} \mathrm{~kg}^{-1}$ in DM.

Chemical analysis of the soil showed values of $\mathrm{pH} 6.0\left(\mathrm{CaCl}_{2}\right), 60.8 \%$ of base saturation; 41.5 $\mathrm{g} \mathrm{dm}^{-3}$ organic matter (OM), $12.8 \mathrm{mg}$ phosphorus $\mathrm{dm}^{-1}$ (P-Mehlich), and $48.7 \mathrm{mg}$ of potassium $\mathrm{dm}^{-1}$. In September 2013, $200 \mathrm{~kg}$ of NPK (00-20-20) and $100 \mathrm{~kg} \mathrm{~N}$ (as urea) ha-1 were distributed over two periods: October 2013 and February 2014.

Forage samples were harvested every 28 days to adjust stocking rates to maintain the treatment being studied, and were adjusted monthly according to forage availability. Forage collection used the square technique for determining the picket forage availability for the herbage allowance adjustments. A total of 10 samples were harvested to $5.0 \mathrm{~cm}$ from ground level using a metal square of $1.0 \mathrm{~m}^{2}$ initiated by a randomly placed picket.

Data collected included green mass forage (GM) $\mathrm{ha}^{-1}$, production of DM ha- ${ }^{-1}$, chemical composition, percentage of sheet, percentage of culm, percentage of dead material (senescent), and leaf:stem ratio. The proportion of each morphological component was expressed as a percentage (\%) of total weight. Each sample was divided into two parts; one was used for estimating the total forage mass ( $\mathrm{kg}$ DM $\mathrm{ha}^{-1}$ ) and the other was used to form composite samples from manually separated sheet (leaf lamina from ligule), stem (culm and sheath), dead material (senescent), and the dried samples were placed in a forced ventilation greenhouse at $55{ }^{\circ} \mathrm{C}$ for $72 \mathrm{~h}$, weighed, and then ground for laboratory testing.

The height of the sward was measured using a 1-m ruler, graduated in cm, every 28 days, with 30 random points measured per paddock. The canopy height at each point was the mean height of the upper curvature of the sheets around the ruler.

The DM, OM, and crude protein (CP) were determined according to the Association of Official Analytical Chemists (AOAC, 2000), while the values of neutral detergent fiber (NDF) and acid detergent fiber (ADF) were determined from Van Soest et al. (1985). In vitro digestibility of DM and NDF (IVNDFD) of B. brizantha cv. Marandu pastures was determined using a DAISY incubator, following the method of Holden (1999).

The amount of DM (kg DM 100-1 BW) forage for each treatment was calculated by summing the DM mass present in the paddock and plant growth divided by the total $\mathrm{BW}$ of the animals kept in the paddock over a 28-day period. The load adjustment was based on the estimation of DM forage added to the forage accumulation rate from the previous period, which was designed for the following period.

The average daily gain (ADG) of heifers was estimated as the difference between the initial and final BW divided by the number of days between each weighing (28 days). The hot carcass weight (HCW, kg carcass) was obtained after slaughter and the removal of the head, hide, intestinal tract, and internal organs.

The carcass yield (CY) as a percentage was obtained as the ratio between the final $\mathrm{BW}$ and hot carcass weight. The weight in arroba (@) was determined by dividing the HCW by 15 . 
The stocking rate in animal unit (AU) $\mathrm{ha}^{-1}$ was determined by the ratio of mean BW of heifers per hectare and one animal unit $(=450 \mathrm{~kg} \mathrm{BW})$. The grazing method used 28 days of grazing time. In calculating of stocking rate were considered for purposes of calculating evaluator animals and also weight animals regulatory in period that they remained on the picket line to herbage allowance.

Multiple supplements were provided once daily at $0.4 \% \mathrm{BW}$ and adjusted at every weighing. The supplement was composed of $880 \mathrm{~g} \mathrm{~kg}^{-1} \mathrm{DM}, 200$ $\mathrm{g} \mathrm{kg}^{-1}$ crude protein in DM, $20 \mathrm{~g} \mathrm{~kg}^{-1}$ of $\mathrm{Ca}$ in $\mathrm{DM}$, $8 \mathrm{~g} \mathrm{~kg}^{-1} \mathrm{P}$ in DM, and $550 \mathrm{~g} \mathrm{~kg}^{-1} \mathrm{TDN}$ in DM. The animals received water ad libitum.

The composition of the economic/financial results examined the revenues related to animal sale values considering average stocking during the experimental period. The composition of the total cost included: purchase of animals (purchase value per animal), land lease (15\% of the value paid in the period per animal), cost of supplementation (average intake per animal), supplies for fertilization of pastures ( $\mathrm{R} \$$ per hectare), manpower (wages, vacation, 13th salary, and related charges of an employee for the entire trial period), and vermifuge (one dose per animal).

For economic/financial analysis of the investment, the present value (PV) and profitability margin (PM) were used. When calculating the PV, up to three discount rates on annual net flow of each herbage allowance were applied. The rates were 6,10 , and $12 \%$ per year (a.a.). The lower rate is associated with the remuneration obtained from the financial market for conservative investments, while for the higher rate (12\% a.a.), an award was added for business risk. To calculate the PV (ROSS et al., 2008) the following formula was used:

$$
\mathrm{PV}=\frac{\mathrm{ncf}}{(1+\mathrm{i})^{\mathrm{n}}}
$$

where ncf $=$ net cash flow, $\mathrm{i}=$ minimum attractiveness rate (opportunity cost), and $\mathrm{n}=$ number of periods of cash flow.

The profitability margin (ROSS et al., 2008) corresponds to the return regarding the revenue, i.e., it measures the relationship between net cash flow and revenue and is obtained by the formula:

$$
\mathrm{PM}=\frac{\text { ncf }}{\text { revenue }} \times 100
$$

where $\mathrm{PM}=$ profitability margin and $\mathrm{ncf}=$ net cash flows.

The experimental animals were treated according to the guidelines of Ethics, Bioethics, and Animal Welfare and approved by the Animal Ethics Committee and Protocol 610/2014.

The variables of forage characteristics, nutritional value, production performance, and carcass characteristics were evaluated by analysis of variance (ANOVA) and the means compared using Tukey's test at 5\% probability.

\section{Results and Discussion}

There was a significant effect on the nutritive value of $B$. brizantha cv. Marandu, in the water period, as a function of herbage allowance (Table 1). Treatment with $15 \mathrm{~kg} \mathrm{DM} 100^{-1} \mathrm{BW}$ herbage allowance showed lower levels of CP, IVDMD, and IVNDFD than the 5 and $10 \mathrm{~kg} \mathrm{DM} 100^{-1} \mathrm{BW}$ herbage allowances. When the allowance was increased to $15 \mathrm{~kg}$ DM $100^{-1} \mathrm{BW}$ the NDF content also increased, which negatively interferes with IVDMD. 
Table 1. Chemical composition and in vitro digestibility (IVD) of the leaf and stem of Brachiaria brizantha cv. Marandu pastures for three herbage allowances $\left(\mathrm{kg} \mathrm{DM} 100^{-1} \mathrm{BW}\right)$ in a continuous grazing system.

\begin{tabular}{|c|c|c|c|c|c|}
\hline \multirow{2}{*}{ Variable } & \multicolumn{3}{|c|}{ Herbage allowance (kg DM 100-1 BW) } & \multirow{2}{*}{ CV $(\%)$} & \multirow{2}{*}{$\mathrm{P}$} \\
\hline & 5 & 10 & 15 & & \\
\hline \multicolumn{6}{|l|}{ Leaf } \\
\hline Dry matter $(\%)$ & 29.66 & 29.76 & 30.01 & 8.42 & NS \\
\hline Crude protein $(\% \mathrm{DM})$ & $11.34 \mathrm{a}$ & $10.98 \mathrm{a}$ & $9.13 \mathrm{~b}$ & 9.52 & 0.001 \\
\hline Organic matter (\% DM) & 90.14 & 89.80 & 90.14 & 8.08 & NS \\
\hline Neutral detergent fiber $(\% \mathrm{DM})$ & $67.14 \mathrm{c}$ & $72.06 \mathrm{~b}$ & $76.75 \mathrm{a}$ & 10.91 & 0.001 \\
\hline Acid detergent fiber (\% DM) & $36.62 \mathrm{c}$ & $39.13 \mathrm{~b}$ & $42.28 \mathrm{a}$ & 10.90 & 0.001 \\
\hline IVD dry matter (\%) & $55.70 \mathrm{a}$ & $54.01 \mathrm{a}$ & $50.83 \mathrm{~b}$ & 14.09 & 0.001 \\
\hline IVD neutral detergent fiber $(\%)$ & $47.26 \mathrm{a}$ & $46.36 \mathrm{a}$ & $43.50 \mathrm{~b}$ & 15.60 & 0.001 \\
\hline \multicolumn{6}{|l|}{ Stem } \\
\hline Dry matter $(\%)$ & 27.71 & 27.69 & 27.65 & 18.18 & NS \\
\hline Crude protein $(\% \mathrm{DM})$ & 6.51 & 6.77 & 6.99 & 12.36 & 0.384 \\
\hline Organic matter (\% DM) & 92.05 & 92.27 & 92.01 & 0.65 & NS \\
\hline Neutral detergent fiber (\% DM) & $81.05 \mathrm{~b}$ & $83.36 \mathrm{a}$ & $83.68 \mathrm{a}$ & 4.10 & 0.002 \\
\hline Acid detergent fiber (\% DM) & 48.50 & 49.03 & 48.36 & 4.12 & NS \\
\hline IVD dry matter (\%) & 43.83 & 43.05 & 42.77 & 16.07 & 0.365 \\
\hline IVD neutral detergent fiber (\%) & 34.86 & 34.13 & 35.29 & 18.05 & 0.389 \\
\hline
\end{tabular}

Means followed by different letters differ by Tukey's test at 5\% probability. DM: dry matter; BW: body weight; CV: coefficient of variation; P: $p$-values; NS: not significant.

The 5 and $10 \mathrm{~kg} \mathrm{DM} 100^{-1} \mathrm{BW}$ allowances had higher values of IVDMD, which can be explained by the higher CP content and lower NDF content in the leaves, and increased leaf:stem ratio in the lower forage allowances. Treatment with $15 \mathrm{~kg}$ DM 100${ }^{1} \mathrm{BW}$ herbage allowance provided conditions for the $B$. brizantha cv. Marandu to accumulate more constituents in the cell wall during the water period, as the increase in herbage allowance was due to the increase in forage mass. Ribeiro et al. (2014) found no significant differences in the chemical composition (CP, NDF, and ADF) or the DM digestibility, but the increase in allowance in their study was through area increase and not through herbage mass increase.

For the $15 \mathrm{~kg} \mathrm{DM} 100^{-1} \mathrm{BW}$ herbage allowance, the pasture showed a lower proportion of leaves and lower nutritional value (Table 1) because of higher NDF levels in leaves and stems that may have negatively influenced the DM digestibility. The cause of this is that when the herbage allowance is increased the NDF and ADF contents increased in the leaf and stem components. Owing to lower stocking and ease of selection by animals, stem elongation may have been favored, because the proportion of the stem, and consequently the cell wall constituents, was increased, requiring more nutrients to sustain the plants.

According to Norton (1982), with advancing physiological age of the plants occurs replacement of cell content per cell wall, as well as transformation of the wall due to the emergence of a secondary wall, with greater participation of cellulose and lignin, and the beginning of the senescence process. Euclides et al. (2007) reported that, as the plant matures, the concentration of the potentially digestible components tends to decrease.

It was observed that when defining grazing management based on the herbage allowance, 
the structural characteristics of the pasture are influenced. When reducing the forage allowance, the proportion of leaves increases. The proportion of stems in the 10 and $15 \mathrm{~kg}$ DM $100^{-1} \mathrm{BW}$ forage treatments were higher than in the $5 \mathrm{~kg}$ DM $100^{-1}$
BW forage treatment (Table 2). Similarly, Batistel et al. (2012) found a reduction in the proportion of leaves and an increase in the proportion of stems when they increased the forage allowance in their study from 10 to $15 \mathrm{~kg}$ DM $100^{-1} \mathrm{BW}$.

Table 2. Means of structural and morphological characteristics of Brachiaria brizantha cv. Marandu pastures for three herbage allowances $\left(\mathrm{kg}\right.$ DM $\left.100^{-1} \mathrm{BW}\right)$ in a continuous grazing system.

\begin{tabular}{lccccc}
\hline \multirow{2}{*}{ Variable } & \multicolumn{2}{c}{ Herbage allowance $(\mathrm{kg} \mathrm{DM}$} & $\left.100^{-1} \mathrm{BW}\right)$ & \multirow{2}{*}{ CV (\%) } & \multirow{2}{*}{$\mathrm{P}$} \\
\cline { 2 - 4 } & 5 & 10 & 15 & & \\
\hline Leaf proportion (\%) & $42.40 \mathrm{a}$ & $38.20 \mathrm{~b}$ & $33.88 \mathrm{c}$ & 7.60 & 0.002 \\
Stem proportion (\%) & 46.84 & 47.48 & 47.92 & 7.76 & 0.398 \\
Dead material proportion (\%) & $10.76 \mathrm{c}$ & $15.32 \mathrm{~b}$ & $18.20 \mathrm{a}$ & 8.31 & 0.003 \\
Leaf:stem ratio & $1.22 \mathrm{a}$ & $1.03 \mathrm{~b}$ & $0.83 \mathrm{c}$ & 7.68 & 0.002 \\
Production total green mass $\left(\mathrm{kg} \mathrm{ha}^{-1}\right)$ & $4864.30 \mathrm{c}$ & $6265.53 \mathrm{~b}$ & $6732.15 \mathrm{a}$ & 13.70 & 0.001 \\
Production total DM $\left(\mathrm{kg} \mathrm{ha}^{-1}\right)$ & $1505.01 \mathrm{~b}$ & $2016.25 \mathrm{a}$ & $2187.95 \mathrm{a}$ & 13.70 & 0.001 \\
Production DM leaf $\left(\mathrm{kg} \mathrm{ha}^{-1} \mathrm{month}^{-1}\right)$ & $611.72 \mathrm{c}$ & $712.29 \mathrm{~b}$ & $684.48 \mathrm{a}$ & 13.70 & 0.001 \\
Sward height $(\mathrm{cm})$ & $21.50 \mathrm{c}$ & $32.40 \mathrm{~b}$ & $41.20 \mathrm{a}$ & 19.50 & 0.001 \\
\hline
\end{tabular}

Means followed by different letters differ by Tukey's test at 5\% probability. DM: dry matter; BW: body weight; CV: coefficient of variation; $\mathrm{P}$ : $p$-values.

An important variable is the dead material proportion; through increasing the herbage allowance, the dead material proportion is also increased. This can be related to the higher selection by animals to newer tissue, which agrees with Euclides et al. (2009) who showed that when the herbage allowance is high, the dead material and stems may limit the ease of selection and forage apprehension by the animal, consequently decreasing the intake. The animal selects its grazing intake, preferably the leaves because of the ease of acquisition, ensuring lower energy expenditure for harvest in relation to the stem (CARLOTO et al., 2011).

The treatment with $5 \mathrm{~kg} \mathrm{DM} 100^{-1} \mathrm{BW}$ herbage allowance showed the highest leaf:stem ratio. With the smallest stocking rate proportional to the increased allowance of fodder, there was greater elongation of the stem and the leaf proportion gradually reduced. This may contain a greater contribution of assimilates in the reproductive than in the vegetative structures, thus reducing the leaf:stem ratio and resulting in an increased mass production of fodder. According to Bauer et al. (2011), a high leaf:stem ratio represents forage with higher CP content and greater digestibility, increased forage acquisition facility, and consequently higher intake. The lowest herbage allowances (5 and 10 $\mathrm{kg}$ DM $100^{-1} \mathrm{BW}$ ) showed higher nutritional values and digestibility. This may promote better animal performance by providing better diet quality (Table 3). Euclides et al. (2009) found positive correlations between the ADG and the leaf:stem ratio during the water period.

The height of pastures was influenced by the herbage allowance (Table 2), where pastures with greater herbage allowances showed the highest heights and consequently larger forage masses. Trindade et al. (2012) reported an increase in forage mass and canopy height with increasing allowance of 4 for $16 \mathrm{~kg} \mathrm{DM} 100^{-1} \mathrm{BW}$. Correlating the height of the pasture, forage production, proportion of 
leaves, and weight gain, the $10 \mathrm{~kg}$ DM $100^{-1} \mathrm{BW}$ herbage allowance averaged $32.4 \mathrm{~cm}$, which is above the value recommended by Paula et al. (2012) for $B$. brizantha cv. Marandu pastures. In continuous stocking, the recommended height is between 15 and $30 \mathrm{~cm}$ during the water period. The $5 \mathrm{~kg} \mathrm{DM}$ $100^{-1} \mathrm{BW}$ herbage allowance showed lower canopy height; however, this stocking rate showed a higher proportion of leaves and better nutritional value, although lower weight gain per animal was found.

Table 3. Performance production and carcass characteristics of Nellore heifers in Brachiaria brizantha cv. Marandu pastures for three herbage allowances $\left(\mathrm{kg} \mathrm{DM} 100^{-1} \mathrm{BW}\right)$ in a continuous grazing system.

\begin{tabular}{|c|c|c|c|c|c|}
\hline \multirow{2}{*}{ Variable } & \multicolumn{3}{|c|}{ Herbage allowance (kg DM 100-1 BW) } & \multirow{2}{*}{$\mathrm{CV}(\%)$} & \multirow{2}{*}{$\mathrm{P}$} \\
\hline & 5 & 10 & 15 & & \\
\hline BW initial (kg animal $\left.{ }^{-1}\right)$ & 200.47 & 201.00 & 201.14 & 5.13 & NS \\
\hline BW final $\left(\mathrm{kg}\right.$ animal $\left.{ }^{-1}\right)$ & $301.27 \mathrm{c}$ & $381.00 \mathrm{a}$ & $352.34 \mathrm{~b}$ & 9.62 & 0.001 \\
\hline Total weight gain $(\mathrm{kg})$ & $100.80 \mathrm{c}$ & $180.00 \mathrm{a}$ & $151.20 \mathrm{~b}$ & 7.76 & 0.001 \\
\hline Average daily gain weight $\left(\mathrm{kg} \mathrm{day}^{-1}\right)$ & $0.42 \mathrm{c}$ & $0.75 \mathrm{a}$ & $0.63 \mathrm{~b}$ & 7.76 & 0.001 \\
\hline Yield carcass (\%) & 51.02 & 51.12 & 51.08 & 7.75 & 0.369 \\
\hline Hot carcass weight (kg) & $153.71 \mathrm{c}$ & $194.80 \mathrm{a}$ & $180.00 \mathrm{~b}$ & 7.75 & 0.001 \\
\hline Weight in arrobas $\left(@\right.$ animal $\left.^{-1}\right)$ & $10.25 \mathrm{c}$ & $12.99 \mathrm{a}$ & $12.00 \mathrm{~b}$ & 2.75 & 0.001 \\
\hline Average stocking rate $\left(\mathrm{AU} \mathrm{ha}^{-1}\right)$ & $3.35 \mathrm{a}$ & $1.87 \mathrm{~b}$ & $1.26 \mathrm{c}$ & 9.25 & 0.001 \\
\hline Weight gain ha ${ }^{-1}$ day $^{-1}\left(\mathrm{~kg} \mathrm{ha}^{-1}\right)$ & $2.52 \mathrm{a}$ & $2.16 \mathrm{~b}$ & $1.29 \mathrm{c}$ & 8.50 & 0.001 \\
\hline Supplement intake $\left(\mathrm{kg} \mathrm{day}^{-1}\right)$ & $1.00 \mathrm{~b}$ & $1.16 \mathrm{a}$ & $1.11 \mathrm{a}$ & 9.13 & 0.002 \\
\hline
\end{tabular}

Means followed by different letters differ by Tukey's test at 5\% probability. DM: dry matter; BW: body weight; CV: coefficient of variation; P: p-values; AU: animal unit (450 kg BW); @ (arroba): 15 kg carcass.

Carlotto et al. (2011) evaluated the nutritional value and animal production in $B$. brizantha $\mathrm{cv}$. Xaraés pastures managed at different heights, under a continuous grazing system during the water period, and observed that forage production decreased with increasing grazing intensity showed the highest nutritional value. The authors found a decreasing trend in ADG in animals as the height of the pastures were increased, which is similar to that observed in the lower and higher herbage allowance in the present study.

The treatment of $15 \mathrm{~kg}$ DM $100^{-1} \mathrm{BW}$ showed higher herbage canopy height and higher proportion of stems (Table 2), which probably favored sub grazing and resulted in losses in forage quality showing higher NDF content and digestibility of leaves. This may have resulted from increased competition for light by plants. Santos et al. (2011) found that pastures with greater heights feature higher elongation stem rates, which may occur owing to higher competition for light among tillers.

The $10 \mathrm{~kg}$ DM $100^{-1} \mathrm{BW}$ allowance had higher individual performance, both for ADG and HCW (Table 3), as it is related to increased availability of forage, nutritive value, pasture height (Tables 1 and 2 ), and leaf:stem ratio. However, the $5 \mathrm{~kg} \mathrm{DM} 100^{-1}$ BW forage treatment showed higher weight gain per area $\left(\mathrm{kg} \mathrm{ha}^{-1}\right.$ day $\left.^{-1}\right)$, yet the forage mass availability was lower, which may have impaired the individual weight gain that was seen (Table 3).

Owing to the greater number of heifers per area in the $5 \mathrm{~kg} \mathrm{DM} 100^{-1} \mathrm{BW}$ treatment, the grazing pressure was greater, resulting in animals decreasing their diet selection based on the amount of available forage, which reduces individual weight gain (Table 3). Results from this study demonstrate that when the herbage allowance is increased, the individual 
weight gain is also increased (Table 3). Rezende et al. (2015) report that the B. brizantha $\mathrm{cv}$. Marandu pasture has high positive correlation between DM availability and DM green leaves with ADG and weight gain per area per day in summer. The authors also emphasize that weight gain per animal and per area is influenced by stocking rate, reaching maximum values when the availability of green leaves is greatest.

When the herbage allowance is decreased the stocking rate per area is increased (Table 3 ) and the individual weight gain decreases, however, more weight gain per area occurs, as seen in the $5 \mathrm{~kg}$ DM $100^{-1} \mathrm{BW}$ treatment in this study. Treatment

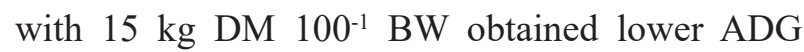
than treatment with $10 \mathrm{~kg}$ DM $100^{-1} \mathrm{BW}$ forage allowance, which is related to the pasture structure (Table 2) and nutritional value (Table 1), which favored the $10 \mathrm{~kg}$ DM $100^{-1} \mathrm{BW}$ herbage allowance treatment and obtained better animal performance.

According to Machado et al. (2008), herbage allowances between 8 and $12 \mathrm{~kg} \mathrm{DM} 100^{-1} \mathrm{BW}$ allow animals to intake and higher quality leaves. Barbosa et al. (2006) reported that the most consistent forage allowance for the highest association between ADG, gain per hectare, and dynamics of tillering was

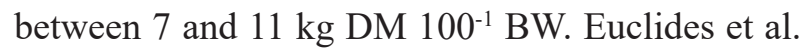
(2009) evaluated the performance of steers and their relationship with the characteristics of $B$. brizantha cv. Marandu pastures and found a gain of $0.74 \mathrm{~kg}$ day $^{-1}$ during the water period and at a stocking rate of 2.7 AU ha', and the forage averaged $99 \mathrm{~g} \mathrm{~kg}^{-1}$ $\mathrm{CP}$ in DM and leaf:stem ratio of 1.9. Values of ADG were similar to those observed in the $10 \mathrm{~kg}$ DM herbage allowance from this study (Table 3), although the stocking rate was $1.87 \mathrm{AU} \mathrm{ha}^{-1}$ and the leaf:stem ratio was 1.03 .

Treatment with $5 \mathrm{~kg}$ DM $100^{-1} \mathrm{BW}$ herbage allowance provided to the production system a higher stocking rate and greater weight gain per hectare, however, individual ADG and mass production of forage were lower (Table 3 ). If the purpose of the agricultural property is for greater production per hectare, then with higher stocking rates it is necessary to increase forage production for pastures so that the degradation process is avoided. According to Barbosa et al. (2013), high stocking rate coupled with inadequate management can lead to grassland degradation, generating the need for fertilization in the short term or the introduction of measures for pasture recovery.

Regardless of the herbage allowance, all treatments showed economic viability (Table 4); however, the $10 \mathrm{~kg} \mathrm{DM} 100^{-1} \mathrm{BW}$ forage treatment showed a higher margin of profitability. This was based on the $10 \mathrm{~kg} \mathrm{DM} 100^{-1} \mathrm{BW}$ forage treatment having the highest animal performance coupled with the adjustment of stocking rate and response of grasses. In the present study, the area used for the production of animals was leased, which reduces the cost of improvements, facilities, and depreciation.

Among the total costs, the most onerous activity was the acquisition of animals, followed by obtaining the multiple supplements, lease of the land, fertilization of pastures, and worming of animals. The breakdown of the total cost is as follows: $54.74 \%$ spent on the purchase of animals, $20.05 \%$ on food supplements, $12.10 \%$ on the lease of land, $8.41 \%$ for pasture fertilization, $3.67 \%$ on labor, and $0.03 \%$ on vermifuge. From this breakdown of costs, it can be noted that the most costly parts are the purchase of the animals and the multiple supplements. Considering that the acquisition cost of animals is equivalent to $54.74 \%$ of the total cost, this highlights the importance of marketing, both during the acquisition and for future sales, which is linked to the proper management of pastures, as well as the adjustment of the herbage allowance.

According to the calculations of $\mathrm{PV}$, the discount rates of 6,10 , and $12 \%$ a.a. were all positive, demonstrating that the production of heifers depending on the herbage allowance in the water period are economically viable livestock, as 
they were valued more than the potential interest earned on market investments. The PV measures the relationship between a currency today and a currency in the future, which is important in deciding in advance about an investment project. Ross et al. (2008) reported that this relationship is called value of money over time and becomes important in areas such as capital budgeting, lease versus purchase decisions, accounts receivable analyses, and financing schemes. Net margin is a measure that relates the success of the company with the sales profit; Assaf Neto (2012) states that the net margin measures the efficiency of a company in producing profit through sales.

Tabela 4. Economic and financial viability, for a year, of final Nellore heifers in Brachiaria brizantha cv. Marandu pastures for three herbage allowances ( $\mathrm{kg} \mathrm{DM} 100^{-1} \mathrm{BW}$ ) in a continuous grazing system.

\begin{tabular}{lccc}
\hline \multirow{2}{*}{ Item } & \multicolumn{3}{c}{ Herbage allowance (kg DM 100 $\left.0^{-1} \mathrm{BW}\right)$} \\
\cline { 2 - 4 } & 5 & 10 & 15 \\
\hline Total revenue (R\$) & 145294.00 & 94112.00 & 59220.00 \\
Total cost (R\$) & 130226.00 & 71852.00 & 50675.00 \\
\hline Acquisition animals (R\$) & 76950.00 & 39330.00 & 26790.00 \\
Land lease (R\$) & 17010.00 & 8694.00 & 5922.00 \\
Protein-energy supplement (R\$) & 24300.00 & 14407.00 & 9391.00 \\
Fertilization pastures (R\$) & 6760.00 & 6760.00 & 6760.00 \\
Manpower (R\$) & 5163.00 & 2639.00 & 1797.00 \\
Vermifuge (R\$) & 43.20 & 22.10 & 15.05 \\
Net cash flow (R\$) & 15067.00 & 22260.00 & 8545.00 \\
Profit margin (\%) & 10.37 & 23.65 & 14.43 \\
Present value the 6\% a.a. (R\$) & 14214.00 & 21000.00 & 8061.00 \\
Present value the 10\% a.a. (R\$) & 13697.00 & 20236.00 & 7768.00 \\
Present value the 12\% a.a. (R\$) & 13453.00 & 19875.00 & 7629.00 \\
\hline
\end{tabular}

DM: dry matter; BW: body weight; a.a.: per year.

If the aim is to obtain higher stocking rates per hectare, herbage allowance should be decreased, and more animals acquired to sustain the stocking level, thus the production cost will be increased. However, this results in higher grazing pressures that might be reflected in the pasture response as a smaller mass of forage production (Table 2) and consequently animal performance. The production of heifers in B. brizantha cv. Marandu pastures, owing to the adjustment of forage allowance combined with good weight gains per animal and per area, allows the activity to be attractive and economically viable. The present study provides a cost parameter for cattle breeders, and may contribute to better planning activities and rational management proposals in the production system.

\section{Conclusions}

The herbage allowance of $5 \mathrm{~kg}$ DM $100^{-1} \mathrm{BW}$ provided greater nutritional value and morphological characteristics of pasture, leading to increased stocking rate and greater weight gain per hectare.

The herbage allowance of $10 \mathrm{~kg}$ DM $100^{-1} \mathrm{BW}$ be applied to obtain higher animal performance and better economic viability of heifers in $B$. brizantha cv. Marandu pastures in a continuous grazing system that are receiving protein-energy supplementation. 


\section{References}

ASSAF NETO, A. Finanças corporativas e valor. 6. ed. São Paulo: Atlas, 2012. 800 p.

ASSOCIATION OF OFFICIAL ANALYTICAL CHEMISTS - AOAC. Official methods of analysis. $17^{\text {th }}$ ed. Gaithersburg, MD: AOAC, 2000.

BARBOSA, M. A. A. F.; CASTRO, L. M.; BARBERO, R. P.; BRITO, V. C.; MIORIN, R. L.; SILVA, L. D. F.; RIBEIRO, E. L. A.; MIZUBUTI, I. Y. Desempenho de bovinos de corte em pastos de Brachiaria brizantha cv. Xaraés manejados em diferentes alturas de pastejo. Semina: Ciências Agrárias, Londrina, v. 34, n. 6, p. 4133-4144, 2013.

BARBOSA, M. A. A. F.; NASCIMENTO JÚNIOR, D.; CECATO, U. Dinâmica da pastagem e desempenho de novilhos em pastagem de capim-tanzânia sob diferentes ofertas de forragem. Revista Brasileira de Zootecnia, Viçosa, MG, v. 35, n. 4, p. 1594-1600, 2006.

BATISTEL, F.; SOUZA, J.; TICIANI, E.; BALDIN, M.; DRESCH, R.; FERNANDES, D.; OLIVEIRA, D. E. de. Diferentes ofertas de forragem e a produção de leite em vacas mestiças Holandês x Gir. Ciência Rural, Santa Maria, v. 42, n. 5, p. 870-874, 2012.

BAUER, M. O.; PACHECO, L. P. A.; CHICHORRO, J. F.; VASCONCELOS, L. V.; PEREIRA, D. F. C. Produção e características estruturais de cinco forrageiras do gênero Brachiaria sob intensidades de cortes intermitentes. Ciência Animal Brasileira, Goiânia, v. 12, n. 1, p. 17-25, 2011.

BERNARDINO, F. S.; TONUCCI, R. G.; GARCIA, R.; NEVES, J. C. L.; ROCHA, G. C. Produção de forragem e desempenho de novilhos de corte em um sistema silvipastoril: efeito de doses de nitrogênio e oferta de forragem. Revista Brasileira de Zootecnia, Viçosa, MG, v. 40, n. 7, p. 1412-1419, 2011.

CARLOTO, M.N.; EUCLIDES, V.P. B.; MONTAGNER, D. B.; LEMPP, B.; DIFANTE, G. S.; PAULA, C. C. L. de. Desempenho animal e características de pasto de capimXaraés sob diferentes intensidades de pastejo, durante o período das águas. Pesquisa Agropecuária Brasileira, Brasília, v. 46, n. 1, p. 97-104, 2011.

EUCLIDES, V. P. B.; FLORES, R.; MEDEIROS, R. N.; OLIVEIRA, M. P. de. Diferimento de pastos de braquiária cultivares Basilisk e Marandu, na região do Cerrado. Pesquisa Agropecuária Brasileira, Brasília, v. 42, n. 2, p. 273-280, 2007.

EUCLIDES, V. P. B.; MACEDO, M. C. M.; VALLE, C. B.; DIFANTE, G. S.; BARBOSA, R. A.; CACERE, E. R. Valor nutritivo da forragem e produção animal em pastagens de Brachiaria brizantha. Pesquisa Agropecuária Brasileira, Brasília, v. 44, n. 1, p. 98-106, 2009.

HOLDEN, L. A. Comparison of methods of in vitro dry matter digestibility for then feeds. Journal of Dairy Science, Madison, v. 82, n. 8, p. 1791-1794, 1999.

MACHADO, L. A. Z.; FABRÍCIO, A. C.; GOMES, A.; ASSIS, P. G. G.; LEMPP, B.; MARASCHIN, G. E. Desempenho de animais alimentados com lâminas foliares, em pastagem de capim-Marandu. Pesquisa Agropecuária Brasileira, Brasília, v. 43, n. 11, p. 16091616, 2008.

NANTES, N. N.; EUCLIDES, V. P. B.; MONTAGNER, D. B.; LEMPP, B.; BARBOSA, R. A.; GOIS, P. O. Desempenho animal e características de pastos de capimPiatã submetidos a diferentes intensidades de pastejo. Pesquisa Agropecuária Brasileira, Brasília, v. 48, n. 1, p. 114-121, 2013.

NORTON, B. W. Differences in plant species in forage quality. In: INTERNATIONAL SYMPOSIUM ON NUTRITIONAL LIMITS TO ANIMAL PRODUCTION FROM PASTURE, 1981, Sta. Lucia. Proceedings... Farnham Royal: Commonwealth Agricultural Bureaux, 1982. p. 89-110.

PAULA, C. C. L.; EUCLIDES, V. P. B.; MONTAGNER, D. B.; LEMPP, B.; DIFANTE, G. S.; CARLOTO, M. N. Estrutura do dossel, consumo e desempenho animal em pastos de capim-Marandu sob lotação contínua. Arquivo de Medicina Veterinária e Zootecnia, Belo Horizonte, v. 64, n. 1, p. 169-176, 2012.

REIS, R. A.; RUGGIERI, A. C.; CASAGRANDE, D. R.; PÁSCOA, A. G. Suplementação da dieta de bovinos de corte como estratégia do manejo das pastagens. Revista Brasileira de Zootecnia, Viçosa, MG, v. 38, p. 147-159, 2009. Suplemento Especial.

REZENDE, C. P.; PEREIRA, J. M.; MACEDO, T. M.; BORGES, A. M. F.; CARVALHO, G. G. P.; LOBÃO, É. S. P.; NICORY, I. M. C. Ganho de peso de novilhos em pastagens de capim-Cameroon e capim-braquiarão. Semina: Ciências Agrárias, Londrina, v. 36, n. 3, p. 2185-2194, 2015. Suplemento 1.

RIBEIRO, A. F.; MESSANA, J. D.; DIAN, P. H. M.; REIS, R. A.; RUGGIERI, A. C.; MALHEIROS, E. B.; BERCHIELLI, T. T. Chemical composition, in vitro digestibility and gas production of Brachiaria managed under different forage allowances. Italian Journal of Animal Science, Pavia, v. 13, n. 1, p. 36-43, 2014.

ROSS, S. A.; WESTERFIELD, R.; JORDAN, B. D. Administração financeira. 8. ed. São Paulo: McGrawHill, 2008. 778 p. 
SANTOS, M. E. R.; FONSECA, D. M.; BRAZ, T. G. S.; SILVA, S. P.; GOMES, V. M.; SILVA, G. P. Características morfogênicas e estruturais de perfilhos de capim-braquiária em locais do pasto com alturas variáveis. Revista Brasileira de Zootecnia, Viçosa, MG, v. 40, n. 3, p. 535-542, 2011.

SCHIO, A. R.; VELOSO, C. M.; SILVA, F. F.; ÍTAVO, L. C. V.; MATEUS, R. G.; SILVA, R. R. Ofertas de forragem para novilhas nelore suplementadas no período de seca e transição seca/águas. Acta Scientiarum. Animal Sciences, Maringá, v. 33, n. 1, p. 9-17, 2011.
TRINDADE, J. K. da; PINTO, C. E.; NEVES, F. P.; MEZZALIRA, J. C.; BREMM, C.; GENRO, T. C. M.; TISCHLER, M. R.; NABINGER, C.; GONDA, H. L.; CARVALHO, P. C. F. Forage allowance as a target of grazing management: implications on grazing time and forage searching. Rangeland Ecology and Management, Road Burns, v. 65, n. 4, p. 382-393, 2012.

VAN SOEST, P. J.; ROBERTSON, J. B.; LEWIS, B. A. Analysis of forage and fibrous foods. Ithaca: Cornell University Press, 1985. 202 p. 